\title{
Characterization of the Fumarase Gene of Bacillus subtilis 168 Cloned and Expressed in Escherichia coli K12
}

\author{
By ANNE MOIR," IAN M. FEAVERS AND JOHN R. GUEST \\ Department of Microbiology. Sheffield University, Sheffield SIO 2TN, UK
}

(Received 30 April 1984)

\begin{abstract}
The fumarase (citG) gene of Bacillus subtilis 168 has been identified in a collection of $\lambda$ phages carrying EcoRI-generated fragments of $B$. subtilis DNA. Regions of the cloned DNA have been subcloned into plasmid vectors, and the ability of prophages and multicopy plasmids to complement Escherichia coli and $B$. subrilis fumarase mutations has been examined. Two EcoRI fragments of 1.5 and $5.1 \mathrm{~kb}$ are both required for fumarase expression in $E$. coli and $B$. subtilis. The level of fumarase activity from a single copy of the $B$. subtilis cir $G$ gene expressed in $E$. coli is approximately one-tenth of that from the normal $E$. coli gene; the level is increased by expression from a pBR322-derived multicopy plasmid. The citG gene has been located within the cloned DNA by transposon mutagenesis and by expression studies, which have also identified a polypeptide of $M_{r} 49000$ as the product of the cirG gene. The properties of a truncated derivative of this polypeptide have indicated the direction of transcription of the cir $G$ gene.
\end{abstract}

\section{INTRODUCTION}

The cirG gene of Bacillus subrilis 168 encoding the tricarboxylic acid cycle enzyme fumarase (EC 4. 2.1.2), is located at $295^{\circ}$ on the genetic map (Rutberg \& Hoch, 1970; Henner \& Hoch, 1980). Lambda phages ( $\lambda$ citG) permitting weak complementation of an Escherichia coli fumarase-deficient mutant have been isolated from a library of $B$. subtilis DNA cloned in $\lambda g t W E S$ (Moir, 1983). The segments of cloned DNA were found to contain two EcoRI fragments of 1.5 and $5.1 \mathrm{~kb}$, which encode a functional cit $G$ gene, at least part of a spore germination locus (gerA; Moir, 1983), and a genetically defined site of rearrangement in trpE26 derivatives of $B$. subtilis 168 (Sammons \& Anagnostopoulos, 1982). It was also shown that the citG4 mutation of $B$. subtilis could be repaired by transformation with the $5.1 \mathrm{~kb}$ fragment purified from agarose gels (Moir, 1983). This paper describes experiments which identify the location of the fumarase gene in the cloned DNA and characterize its expression, transcription polarity and gene product.

\section{METHODS}

Bacterial strains. The derivatives of $E$. coli $\mathrm{K} 12$ and of $B$. subtilis 168 that have been used are listed in Table 1 . Strain EJ1535, previously described as 1535 (Guest \& Roberts, 1983) and BH2919 (Moir, 1983), is a fumarasedeficient derivative of NK-1.

Bacteriophages. Fumarase transducing phages ( $\lambda$ citGI and II) were selected from a gene library provided by $\mathrm{Dr}$ J. A. Hoch (Moir, 1983). Other $\lambda$ citG phages, $\lambda G 142, \lambda G 143$ and $\lambda G 144$, were isolated in an analogous manner from the same library using $\lambda$ Pam 3 as helper (this work). All of the $\lambda$ citG phages retained the vector $\lambda c / 857$ marker and only $\lambda G 143$ and $\lambda G 144$ were sup $F$-dependent (i.e. carried at least the $\lambda S a m 7$ mutation). Helper phages were essential for transduction by the suppressor-independent phages. Other phages were: $\lambda \mathrm{imm}^{34}$, a heteroimmune phage that was used for dilysogen construction; $\lambda G 134$, a $\lambda f u m A$ phage carrying the $E$. colifumarase gene (Guest \& Roberts, 1983), used for comparative purposes; and $\lambda G 78 N$ (גnadC aroP genA; Guest \& Stephens, 1980), which provided a $\lambda c \$ 857$ control in post-infection labelling studies. 
Table 1. Bacterial strains

$\quad$ Strain
E. coli
NK-I
EJ1535
ED8654
RB308
AB2480
S159 ( $\lambda$ ind)
B. subtilis
JH404
AM096
AM099

\section{Genotype}

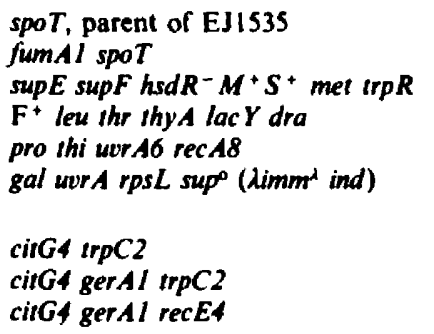

\section{Origin $* /$ reference}

E. Juni
E. Juni
Murray et al. (1977)
R. S. Buxton
P. J. Emmerson
N. E. Murray
J. Hoch
This laboratory
This laboratory

- E. Juni, Department of Microbiology, University of Michigan, USA; R. S. Buxton, NIMR, Mill Hill, London, UK; P. J. Emmerson, Department of Biochemistry, University of Newcastle, UK; N. E. Murray, Department of Molecular Biology, University of Edinburgh, UK; J. Hoch, Research Institute of Scripps Clinic, La Jolla, Calif., USA.

Plasmids. Plasmids constructed in this study are described in Results and illustrated in Fig. 2. Plasmid pHV33 (Primrose Ehrlich, 1981) is a hybrid of pBR322 and a staphylococcal plasmid, pC194, that is capable of replication in $E$. coli and $B$. subtilis. A derivative of pBR322 carrying the $E$. coli fumarase (fum $A$ ) gene, pGSS4 (Guest \& Roberts, 1983), was used in comparative studies.

Media. The rich medium for subculturing $E$. coli and for phage propagation was L broth, or LG broth if used for citric acid cycle mutants (Guest, 1981). A peptone medium (Guest, 1981) was used for phage assays and for selective purposes. Media were solidified with agar (Difco) at 10 or $15 \mathrm{~g} \mathrm{I}^{-1}$ for plates and $6.5 \mathrm{~g} \mathrm{I} \mathrm{I}^{-1}$ for top layers. Strains of $B$. subtilis were routinely grown in Difco Penassay Broth and colonies of $c i t G$ mutants were produced on TBAB agar containing glucose and $\mathrm{MnCl}_{2}$ (Rutberg \& Hoch, 1970). Cit strains of $B$. subtilis were selected on minimal agar (Anagnostopoulos \& Spizizen, 1961) containing 0.5\% sodium DL-lactate as sole carbon source. Accumulation of acids, a characteristic of $\mathrm{Cit}^{-}$strains, was scored on PA agar (Caris \& Hanson, 1971).

Antibiotics used for selection after transformation of $E$. coli by plasmid DNA were ampicillin (at $50 \mu \mathrm{g} \mathrm{ml} \mathrm{I}^{-1}$ ) or tetracycline (at $15 \mu \mathrm{g} \mathrm{ml} l^{-1}$ or $5 \mu \mathrm{g} \mathrm{ml} \mathrm{ml}^{-1}$; see Results) in L or LG agar. Selection of $B$. subtilis transformants carrying plasmids was on $L$ agar containing $3 \mu \mathrm{g}$ chloramphenicol $\mathrm{ml}^{-1}$.

Transformation. Transformation of competent cells of $B$. subtilis was performed as previously described (Warburg \& Moir, 1981). Transformation of $E$. coli was by the method of Lederberg \& Cohen (1974).

Conjugation. The pBR322-derived plasmid pAAM6 was mobilized by and with the F factor of RB308(pAAM6) by conjugation according to the procedure of Guyer (1978).

DNA isolation procedures. Bacteriophage DNA isolation has already been described (Moir, 1983; Spencer \& Guest, 1982). Plasmid DNA from $E$. coli was purified according to Spencer \& Guest (1982). pHV33 DNA was prepared from $B$. subtilis by the method of Niaudet \& Ehrlich (1979). Small scale plasmid preparations (Birnboim \& Doly, 1979) were used routinely for plasmid screening and transformation.

DNA restriction and ligation. Restriction enzymes EcoRI, HindIIl and SafI, and T4 DNA ligase. were purchased from BRL and used under the reaction conditions recommended by the suppliers. DNA fragments were separated by agarose gel electrophoresis and their size estimated as previously described (Spencer \& Guest, 1982). Low melting point agarose was obtained from BRL, and phenol extraction of DNA fragments from this agarose was according to the manufacturer's recommended protocol. Calf intestinal phosphatase (Boehringer) was purified by the method of Efstratiadis et al. (1977) before use according to the manufacturer's recommended procedure.

Enzymology. Exponential cultures ( $250 \mathrm{ml}$ in 2 litre flasks) were grown with shaking in $\mathrm{L}$ broth (with ampicillin, $50 \mu \mathrm{g} \mathrm{ml}-1$, where appropriate) for $4 \mathrm{~h}$ at $30^{\circ} \mathrm{C}$ (dilysogens) or $37^{\circ} \mathrm{C}$ (all other strains) using inocula ( $5 \mathrm{ml}$ ) grown for $16 \mathrm{~h}$ in the same medium. Extracts were prepared and assayed for fumarase (EC 4.2.1.2) by measuring the conversion of L-malate to fumarate according to Guest \& Roberts (1983) and Hill \& Bradshaw (1969). Specific activities are expressed as $\mu \mathrm{mol}$ substrate transformed (mg protein in the high speed supernatant) ${ }^{-1} \mathrm{~h}^{-1}$ at $25^{\circ} \mathrm{C}$.

Analysis of polypeptides formed in UV-irradiated hosts. Polypeptides synthesized after infecting UV-irradiated maltose-grown aerobic cultures of strain S1 59 ( $\lambda$ ind) with transducing phages were labelled with L- $-{ }^{35}$ S)methionine as previously described (Guest et al., 1981). Polypeptides expressed from plasmid-borne genes were labelled by the maxicell procedure of Sancar et al. (1979) by using glucose-grown cultures of strain AB2480 transformed with the relevant plasmids. Radioactive polypeptides were analysed by SDS-polyacrylamide gel electrophoresis as previously described (Guest \& Roberts, 1983). 


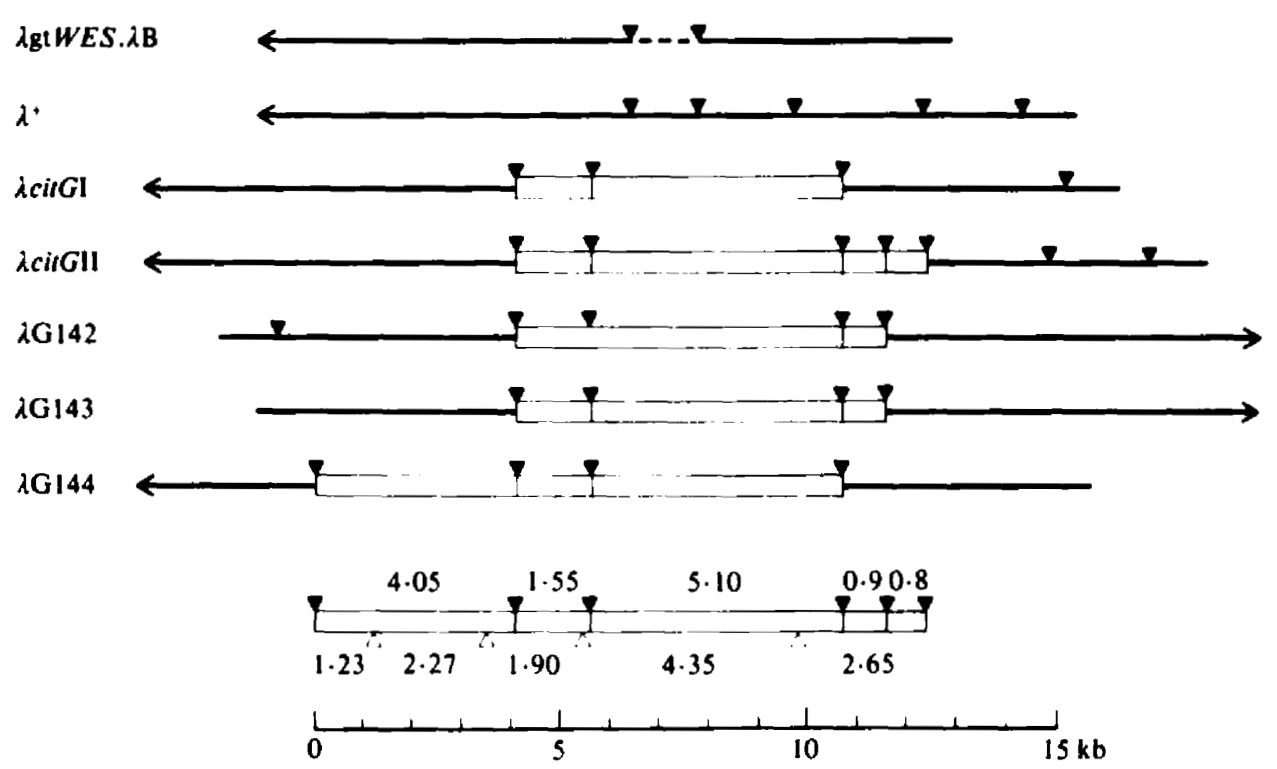

Fig. 1. Restriction patterns of $\lambda$ citG DNA relative to $\lambda^{+}$and $\lambda \mathrm{gt} W E S . \lambda B$ and a restriction map of the corresponding segment of the $B$. subtilis chromosome. Phage DNA is represented by single lines (drawn to a different scale) and the arrowheads mark the phage left arms. The relative positions of the $E c o R I$ $(\nabla)$ and HindII $(\Delta)$ sites, and the sizes of some of the fragments (in kb) are indicated.

\section{RESULTS}

\section{Properties of AcitG phages}

Five $\lambda$ cit $G$ transducing phages have been detected by their ability to complement the fumarase lesion of a fumA mutant of $E$. coli with the formation of lysogen-filled transduction plaques (see Methods). The gross physiological properties of the phages indicated that they were the products of recombination between the original hybrid phages in the gene bank and the helper phages used to supply integration and other functions needed to facilitate transduction. Restriction maps obtained by digesting the phage DNAs with EcoRI and HindIII, separately and in combination, are shown in Fig. 1 . The segments of $B$. subtilis DNA cloned in these phages were clearly identified as a series of overlapping fragments $(6.65$ to $10.7 \mathrm{~kb})$ all containing at least two specific EcoRI subfragments of 1.55 and $5.1 \mathrm{~kb}$. It was concluded that the $B$. subtilis fumarase gene (citG) is very probably expressed from the $6.65 \mathrm{~kb}$ segment that is common to all of the $\lambda$ cir $G$ phages. Since the gene bank was originally constructed from a size-selected fraction (10 to $13 \mathrm{~kb}$ ) of a partial EcoRI digest of B. subtilis DNA, it is likely that the map derived from the cloned fragments corresponds to a continuous $12.4 \mathrm{~kb}$ segment of the $B$. subtilis chromosome, rather than a reassorted set of EcoRI sub-fragments.

\section{Subcloning of DNA into plasmid vectors}

To define the location of genes in the cloned segment, DNA fragments from $\lambda$ citGI and II were subcloned into pHV33, all the plasmid constructions being carried out in $E$. coli.

Plasmids pAAM3 and pAAM4 (Fig. 2) were constructed by ligation of the complete EcoRI digest of $\lambda$ citGI DNA with EcoRI-digested pHV33 DNA, selecting transformants of ED8654 on $\mathrm{L}$ agar containing $15 \mu \mathrm{g}$ tetracycline $\mathrm{ml}^{-1}$. Plasmids pAAM3, containing the $5 \cdot 1 \mathrm{~kb}$ fragment, and pAAM4, carrying the $1.55 \mathrm{~kb}$ fragment, were both identified in a screening of 17 such transformants. Strains carrying pAAM3 grew more slowly on L agar $+15 \mu \mathrm{g}$ tetracycline $\mathrm{ml}^{-1}$ than those carrying pHV33 or pAAM4, and subsequently tetracycline was used at $5 \mu \mathrm{g} \mathrm{ml}^{-1}$ for selective purposes. 


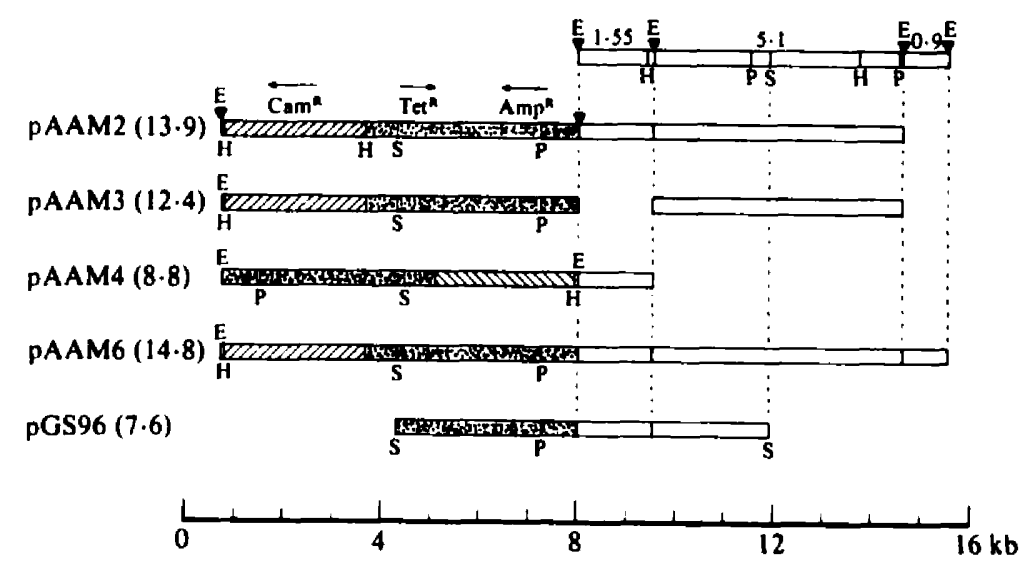

Fig. 2. Physical maps of plasmids containing segments of the cir $G$ region of $B$. subrilis transferred from $\lambda$ citG to pHV 33. Bacterial DNA is denoted by the open bars and vector DNA by stippled bars (pBR322 segment) and hatched bars (pC194 segment). The scale drawings show linear representations of the circular plasmids, their overall sizes (in kb), and the targets for EcoRI (E), HindIII (H), PstI (P) and Sal (S). The approximate positions and polarities of the genes encoding antibiotic resistance are indicated: $\operatorname{Cam}^{R}(c a t) ; \operatorname{Tet}^{R}(t e t)$ and $\operatorname{Amp}^{R}(b l a)$.

In an attempt to obtain plasmids carrying a functional fumarase gene, plasmid DNA from a pool of approximately 600 transformants was used to transform the fumarase mutant EJ1535, selecting transformants on LG $+15 \mu \mathrm{g}$ tetracycline $\mathrm{ml}^{-1}$. Some 1400 colonies were replica plated to peptone medium containing $15 \mu \mathrm{g}$ tetracycline $\mathrm{ml}^{-1}$, and three that grew more strongly were screened for plasmid content. Two carried pHV33, and were probably chromosomal revertants to fum ${ }^{+}$, while the third contained a plasmid carrying 1.55 and $5.1 \mathrm{~kb}$ fragments; this plasmid was designated pAAM2 (Fig. 2). A second plasmid of identical constitution was obtained from a parallel experiment.

DNA fragments of 7 to $8 \mathrm{~kb}$ derived from a partial $E c o R I$ digest of $\lambda c i t G I I$ were purified by excision of appropriately sized fragments after electrophoresis in a low melting point agarose gel. These were ligated with EcoRI-digested and phosphatase-treated pHV33 DNA. Transformants of ED8654 resistant to $5 \mu \mathrm{g}$ tetracycline $\mathrm{ml}^{-1}$ were screened and a plasmid carrying $1.55,5.1$ and $0.9 \mathrm{~kb}$ fragments was retained and designated pAAM6 (Fig. 2).

A deletion derivative of pAAM2, plasmid pGS96, was constructed by religating pAAM2 after $S a / 1$ digestion. This plasmid pGS96 retains the bla gene and replication functions of pBR322, the $1.55 \mathrm{~kb}$ cloned fragment and the proximal part of the $5.1 \mathrm{~kb}$ cloned fragment as far as the single Sal site in the cloned DNA (Fig. 2). The rest of the $5.1 \mathrm{~kb}$ fragment, all of pC194, and part of the pBR322 tet gene were lost.

\section{Complementation and recombination studies in B. subtilis}

Plasmids pAAM3 and pAAM4 (Fig. 2) were transformed into competent cells of the recombination-proficient strain AM096; only pAAM3 could repair the citG4 mutation by recombination. A second genetic marker, gerA $I^{+}$, was $37 \%$ cotransformed with $\operatorname{cirG4^{+}}$; this linkage is similar to that observed using $\lambda c i t G$ phages as donors but is lower than that observed using chromosomal DNA (Moir \& Smith, 1983). Complementation of a fumarase defect was tested by transforming pAAM2 and pAAM3 into competent cells of AM099, a recE4 cirG4 ger $A l$ strain, selecting chloramphenicol resistance. Transformants were scored for their ability to accumulate acids when grown on PA indicator agar containing chloramphenicol. Strain AM099 carrying pAAM 3 formed the characteristic asporogenic and acid-excreting colonies of the $\mathrm{Cit}^{-}$parent; transformants carrying pAAM2 formed mainly $\mathrm{Cit}^{+}$sporogenic colonies, although some $\mathrm{Cit}^{-}$segregants were visible. So, the recombination studies indicate that cir $\mathrm{G}^{+}$ is carried on the $5.1 \mathrm{~kb}$ fragment, and the complementation studies show that the $1.55 \mathrm{~kb}$ 
Fig. 3. Restriction map of the B. subtilis DNA cloned in pGS96 (see Fig. 2). The targets for EcoRI (E), $H$ indIII (H), ClaI (C). Pstl (P) and $S a h$ (S) are indicated. The positions of $\mathrm{Tn} / 000$ insertions studied are indicated by small vertical arrows: those drawn below the map inactivate cir $G$, whereas the one drawn above the map does not. The minimum extent of cirG defined by the $\mathrm{Tn} 1000$ insertions is cross-hatched, and the probable extent of cirG based on the size of the polypeptide product is indicated by the dotted line extensions. The polarity of transcription is indicated by the large arrow.

fragment is also required for expression of a functional fumarase activity in $B$. subtilis. It is therefore concluded that the $\operatorname{cir} G$ gene, or at least the $\operatorname{cit} G$ transcriptional unit, spans the EcoRI target at the junction of 1.55 and $5.1 \mathrm{~kb}$ fragments.

\section{Complementation studies in E. coli}

The plasmids pAAM2, pAAM6 and pGS96 complemented the $E$. colifum $/$ mutant, whereas pAAM 3 and pAAM4 did not. This confirms that DNA flanking the critical EcoRI target contained in pAAM2, pAAM6 and pGS96 is essential for complementing the fumarase lesion.

\section{Mapping of the citG gene by transposon mutagenesis}

Plasmids such as pBR322 and pHV 33 are mobilized by $F$ at a low frequency, the cotransfer usually resulting in their acquiring $\gamma \delta(\operatorname{Tn} 1000)$ from $F$ (Guyer, 1978; De Lencastre et al., 1983). Following its introduction into the $\mathrm{F}^{+}$strain RB308 by transformation, pAAM 6 was transferred to EJ1535 in a conjugation experiment. Amp ${ }^{R}$ exconjugants containing pAAM6 were obtained at a frequency of $2 \times 10^{-3}$ per donor cell by plating on minimal glucose agar containing $100 \mu \mathrm{g}$ ampicillin $\mathrm{ml}^{-1}$. Of 177 such exconjugants, screened by replica plating to $\mathrm{LG}$ plus tetracycline or chloramphenicol and to peptone agar containing ampicillin, 16 had lost tetracycline resistance, none had lost chloramphenicol resistance, but 33 were now Fum ${ }^{-}$. Plasmids isolated from a number of these Fum - strains were mapped by restriction analysis using $E c o R I$ and $S a \Pi$, and the map of $\mathrm{Tn} 1000$ (Guyer, 1978). The estimated positions of the Tn 1000 inserts are shown in Fig. 3. The results indicate that the cit $G$ gene must extend at least $0.05 \mathrm{~kb}$ into the $1.55 \mathrm{~kb}$ fragment and at least $0.8 \mathrm{~kb}$ into the $5.1 \mathrm{~kb}$ fragment. Four Tn 1000 inserts which did not inactivate $c i t G$ were mapped on the cloned DNA. They were located within the $5.1 \mathrm{~kb} E c o \mathrm{RI}$ fragment at $2.3 \mathrm{~kb}, 2.5-2.6 \mathrm{~kb}, 2.7 \mathrm{~kb}$ and $2.9 \mathrm{~kb}$ from its left-hand end as drawn in Fig. 1 . Analysis of a sufficient number of inserts to provide narrower maximum limits was not carried out.

\section{Expression of $B$. subtilis-dericed fumarase in $E$. coli}

Enzymological studies. The fumarase activities of derivatives of the $E$. coli fumA mutant carrying the $B$. subtilis cit $G$ gene in phage and plasmid vectors were compared with the parental strain, and with analogous derivatives carrying the $E$. coli fum $A$ gene in $\lambda G 134$ and pGS54 (Guest \& Roberts, 1983).

The dilysogen EJI535( $\left.\lambda \mathrm{imm}^{434}, \lambda G 142\right)$ contains a single copy of the citG gene whereas EJ1535(pAAM2) and EJ1535(pGS96) contain multiple copies. The results, shown in Table 2, indicate that the fumarase activity expressed from a single copy of the citG gene is quite significant, but is still 8- to 10-fold lower than that from a single copy of the fum $A$ gene (either in the fum $A^{+}$parent or in the mutant carrying a fum $A^{+}$prophage). Expression from pAAM2 and its deletion derivative pGS96 was increased 7 -fold and 10 -fold respectively over that from a single citG ${ }^{+}$prophage copy. The activities expressed from multiple copies of the heterologous $c i t G$ gene are equivalent to those from single copies of the homologous fumA gene. The fumarase 
Table 2. Fumarase activities of lysogens and plasmid-containing strains

\begin{tabular}{|c|c|c|}
\hline Strain & $\begin{array}{l}\text { Relevant } \\
\text { genotype }\end{array}$ & $\begin{array}{c}\text { Fumarase } \\
\text { specific activity }\end{array}$ \\
\hline NK-I & fum $A^{+}$ & 85 \\
\hline EJI535 & fumAl & $<1$ \\
\hline EJIS35 $\left(\operatorname{dimm}^{434}\right)$ & fumAI $I(\lambda)$ & $<1$ \\
\hline EJ1535(גimm $\left.{ }^{434}, \lambda G 142\right)$ & $\operatorname{fum} A I\left(\lambda, \lambda \operatorname{cit} G^{+}\right)$ & 7 \\
\hline EJIS35 $(\lambda G 134)$ & fumAl $\left(\lambda\right.$ fum $\left.A^{+}\right)$ & 58 \\
\hline EJ1535(pBR 322) & $\operatorname{fum} A I$ & $<1$ \\
\hline EJI535(pAAM2) & fumAl $\left(\mathrm{cir} G^{+}\right)$ & 46 \\
\hline EJIS35(pGS96) & fumAl $\left(\operatorname{cir} G^{+}\right)$ & 65 \\
\hline EJI535(pGS54) & fumA $I\left(\right.$ fum $\left.A^{+}\right)$ & 308 \\
\hline
\end{tabular}

\footnotetext{
- Fumarase was assayed as the conversion of malate to fumarate and specific activities are quoted as $\mu \mathrm{mol}$ fumarate produced (mg protein $)^{-1} \mathrm{~h}^{-1}$.
}

activities for fum $A^{+}$strains in Table 2 are higher than those previously reported (Guest \& Roberts, 1983) and reflect the use of mid-exponential rather than early stationary phase cells.

Identification of the citG product. The post-infection labelling and 'maxicell' procedures were used to detect proteins expressed from phage- and plasmid-cloned genes and to identify the citG gene product. By using a lysogen as the host in post-infection labelling studies, incorporation of labelled methionine was limited to a small number of $\lambda$ proteins and to the products of bacterial genes that had been cloned with their own promoters. An autoradiogram of ${ }^{35} \mathrm{~S}$-labelled polypeptides expressed from three $\lambda$ cit $G$ phages and a control phage $(\lambda G 78 N)$ revealed only one product $\left(M_{\mathrm{r}} 49000\right)$ that is common to all $\lambda$ cit $G$ tracks but not found in the controls (Fig. $4 a$ ). Other products expressed only from $\lambda G 144$ were visible at $M_{r}, 67000,25000$ and 24000 and they are presumably encoded by the additional $4.05 \mathrm{~kb}$ segment of $\lambda G 144$ (see Fig. 1).

The maxicell procedure was applied to strains containing plasmids that express the cit $G$ gene (pAAM2 and pGS96), a non-complementing plasmid (pAAM3) and vector controls (pBR322 and pHV33). These confirmed that a polypeptide of $M_{\mathrm{r}} 49000$ is expressed from the cit $G$ region (Fig. $4 b$ ). With pAAM3, this polypeptide was replaced by one of similar intensity at $M_{\mathrm{r}} 42000$, potentially a truncated derivative of the $M_{\mathrm{r}} 49000$ product (Fig. $4 b$ ).

The identification of the $M_{\mathrm{r}} \mathbf{4 9 0 0 0}$ polypeptide as fumarase is strengthened by the properties of pAAM3, which would be expected from complementation, recombination and Tn 1000 mutagenesis studies to carry part but not all of the cit $G$ gene. Furthermore, the replacement of the $M_{\mathrm{r}} 49000$ polypeptide by one of $M_{\mathrm{r}} 42000$ (whose coding requirement would be about $1.2 \mathrm{~kb}$ ) means that the transcription of $c i r G$ should be initiated within the $5.1 \mathrm{~kb} E c o$ RI fragment and continue outwards into the $1.55 \mathrm{~kb}$ fragment, and that the cit $G$ coding region could extend about $1.2 \mathrm{~kb}$ into the $5.1 \mathrm{~kb}$ fragment, as shown in Fig. 3. Labelled polypeptides corresponding to $\beta$ lactamase and chloramphenicol acetyltransferase, at $M_{r} 30000$ and 26000 , respectively, are also indicated in Fig. $4(b)$. A number of other specific polypeptides were labelled to a lesser degree in the maxicells derived from strains carrying pAAM2, pGS96 and pAAM3 (Fig. 4b). However, their significance and origin is as yet uncertain.

\section{Discussion}

The fumarase gene ( $c i t G$ ) of $B$. subtilis has been located within a $12.4 \mathrm{~kb}$ segment of DNA, by a combination of biochemical and genetic methods. The coding region has been correlated with a gene product of $M_{\mathrm{r}} 49000$ which corresponds to about $1.4 \mathrm{~kb}$ of DNA, and the direction of transcription has been established. The location of the cit $G$ promoter has not been defined but the transcriptional unit is not likely to extend beyond the $S a / I$ site upstream of the coding region (Fig. 3), because deletion from this site (to form pGS96) and Tn 1000 insertion close to it (Fig. 3) do not affect cit $G$ expression. The nearest genetic marker yet identified, ger $A 1 I$, maps on the cirG proximal side of a Clal site (Fig. 3) $1.8 \mathrm{~kb}$ from the EcoRI target in citG (I.M.F., unpublished data); this mutation does not inactivate fumarase and defines a rather narrower 
(a)

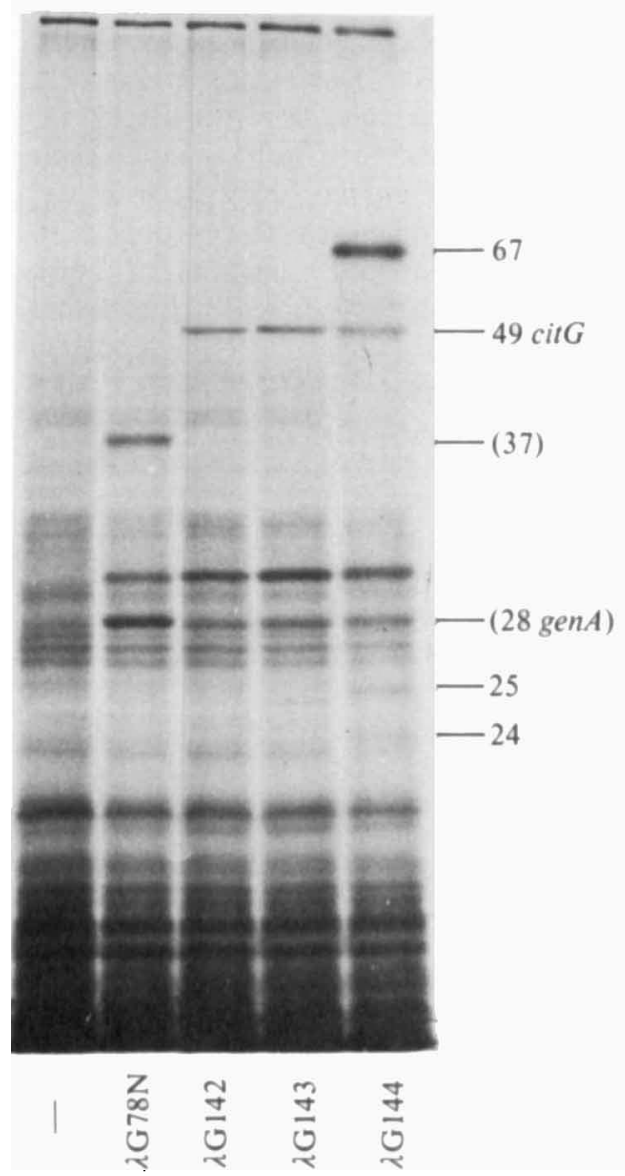

(b)

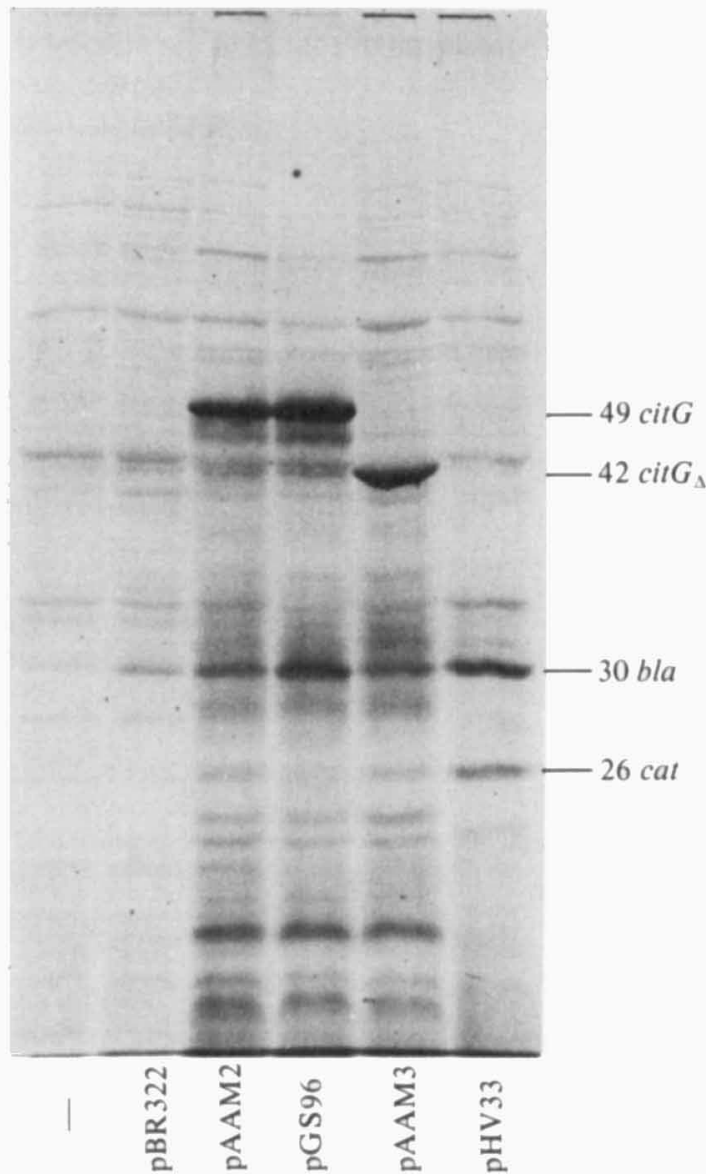

Fig. 4. Autoradiograms of ${ }^{35}$ S-labelied polypeptides expressed from phage and plasmid genes. (a) Cultures of a UV-irradiated $\lambda$ imm lysogen were labelled for $30 \mathrm{~min}$ following infection with $\lambda$ cit $G$ $(\lambda G 142-4)$ and control ( $\lambda G 78 N$ ) phages. (b) Plasmid-containing strains were labelled for $2 \mathrm{~h}$ using the 'maxicell' procedure. Labelled polypeptides were analysed by electrophoresis in SDS-polyacrylamide gels $(10 \%)$ and the estimated sizes $\left(M_{2} \times 10^{-3}\right)$ of some of the products are indicated. Control cells without phages or plasmids were used for the left-hand tracks in both $(a)$ and $(b)$. The polypeptides corresponding to the $B$. subrilis fumarase $(\operatorname{cit} G)$ and a truncated derivative $\left(\boldsymbol{c i r} G_{\Delta}\right)$ are indicated. The products of the vector antibiotic resistance genes, and those expressed from $E$. coli genes of the control (AnadC aroP genA) phage, are shown in parentheses.

limit for the cit $G$ unit. The truncated fumarase gene expressed from the $5 \cdot 1 \mathrm{~kb}$ fragment lacks at most the coding capacity for approximately 7000 daltons of the polypeptide, depending on the extent of the short fusion fragment contributed by extension of the reading frame into the pBR322 sequence. This suggests that the $c i t G$ gene extends for only a few hundred base pairs to the left of the EcoRI target (Fig. 3). This conclusion is consistent with the results from the transposon mutagenesis and is further supported by the properties of a plasmid (pAAM32; I. M.F., unpublished) constructed by insertion of pC194 into the sole HindIII target of pGS96. This plasmid can no longer complement fumA, although a polypeptide indistinguishable in size from the wild-type fumarase is expressed in the maxicell systems. The $c i t G$ gene therefore extends through the HindIII site, but terminates soon after it. Alterations at the extreme Cterminal portion of the protein appear to critically affect the fumarase activity. 
The data presented in this paper provide a basis for current studies aimed at sequencing the fumarase gene for comparison with the analogous $E$. coli gene. The $B$. subtilis fumarase is considerably smaller than that of $E$. coli $(M, 61000$; Guest \& Roberts, 1983; Miles \& Guest, $1984)$ but about the same size as the mammalian enzymes $\left(M_{\mathrm{r}} 48500\right.$; Beeckmans \& Kanarek, 1977). Differences in size between some tricarboxylic acid cycle enzymes have been noted for Gram-positive and Gram-negative organisms, and the former tend to resemble their mammalian counterparts (Weitzman, 1981). The expression of $B$. subtilis fumarase in $E$. coli permits only weak complementation, both at the level of growth rate on selective media and in terms of enzyme activity. This may reflect the rate of transcription and translation of the $B$. subtilis gene in $E$. coli. Nevertheless, the fumarase protein can be labelled efficiently (Fig. 4) and it may be that the heterologous protein functions less well or is less stable in $E$. coli. Even when expressed from a multicopy plasmid (Table 2) the activity attained is lower than that from a single copy of the $E$. coli chromosomal gene.

In addition to cit $G$, the cloned DNA is known to include at least part of a spore germination locus, ger $A$. Definitive studies of the ger $A$ coding regions are being undertaken. Transposon mutagenesis and complementation studies (A. R. Zuberi, I. M. Feavers and A. Moir, unpublished) have identified at least two intact ger $A$ complementation groups and part of a third within the $5.1 \mathrm{~kb}$ fragment; part of one of these complementation groups is present in pGS96. So far, it is not possible to specifically correlate any of these gerA genes with minor labelled polypeptide species expressed in $E$. coli maxicells.

Thanks are due to Drs E. Ferrari and J. Hoch for making available their $\lambda g(W E S$ library of $B$. subtilis DNA and to all those who provided strains. The contributions of $\mathrm{M}$. Calcutt, who performed the Tn 1000 mutagenesis and mapping experiments, and of P. Kiernan who constructed pGS96 and screened enzyme activities, both while undergraduates in this department, are gratefully acknowledged. $\mathbf{R}$. Roberts provided valuable technical assistance. This work was supported by the Science Research Council.

\section{REFERENCES}

Anagnostopoulos, C. \& Spizizen, J. (1961). Requirements for transformation in Bacillus subtilis. Journal of Bacteriology 81, 741-746.

BeEckmans, S. \& Kanarex, L. (1977). A new purification procedure for fumarase based on affinity chromatography. European Journal of Biochemistry $78,437-444$.

Birneolm, H. C. \& DoLY, J. (1979). A rapid alkaline extraction procedure for screening recombinant plasmid DNA. Nucleic Acids Research 7, 1513-1524.

Carls, R. A. Hanson, R. S. (1971). Isolation and characterisation of tricarboxylic acid cycle mutants of Bacillus subtilis. Journal of Bacteriology 106, 848855.

De lencastre, H., Chak, K. F. \& Piggot, P. J. (1983). Use of the Escherichia coli transposon Tn1000 $(y \delta)$ to generate mutations in Bacillus subtilis DNA. Journal of General Microbiology 129, 32033210.

Efstratiadis, A., Vournakis, J. N., Donis-Keller, H., Chaconas, G., Dougall, D. K. Kafatos, F. C. (1977). End labelling of enzymatically decapped mRNA. Nucleic Acids Research 4, 41654174 .

GUEsT, J. R. (1981). Partial replacement of succinate dehydrogenase function by phage- and plasmidspecified fumarate reductase in Escherichia coli. Journal of General Microbiology 122, 171-179.

Guest, J. R. \& Roserts, R. E. (1983). Cloning. mapping and expression of the fumarase gene of Escherichia coli K12. Journal of Bacteriology 153, 588-596.
Guest, J. R. \& Stephens, P. E. (1980). Molecular cloning of the pyruvate dehydrogenase complex genes of Escherichia coli KI2. Journal of General Microbiology 121, 277-292.

Guest, J. R., Cole, S. T. \& Jeyaseelan, K. (1981). Organization and expression of the pyruvate dehydrogenase complex of Escherichia coli. Journal of General Microbiology 127, 65-79.

GUYER, M. S. (1978). The $\gamma \delta$ sequence of $\mathbf{F}$ is an insertion sequence. Journal of Molecular Biology 126, 347-365.

Henner, D. J. Hoch, J. A. (1980). The Bacillus subtilis chromosome. Microbiological Reviews 44, 5782.

HiLl, R. L. BRadshaw, R. A. (1969). Fumarase. Methods in Enzymology 13, 91-99.

Lederberg, E. M. \& COHEN, S. N. (1974). Transformation of Salmonella typhimurium by plasmid deoxyribonucleic acid. Journal of Bacteriology 119, 10721074.

Miles, J. S. \& Guest, J. R. (1984). Complete nucleotide sequence of the fumarase gene, fumA, of Escherichia coli. Nucleic Acids Research 12, 36313642.

MoIR, A. (1983). The isolation of $\lambda$ transducing phages carrying the cir $G$ and ger $A$ genes of Bacillus subrilis. Journal of General Microbiology 129, 303-310.

MotR, A. \& SMITh, D. A. (1983). The genetics of spore germination in Bacillus subtilis. In Fundamental and Applied Aspects of Spores, pp. 89-100. Edited by G. J. Dring. D. J. Ellar \& G. W. Gould. London: Academic Press. 
Murray, N. E., Brammar, W. J. \& Murray, K. (1977). Lambdoid phages that simplify the recovery of in vitro recombinants. Molecular and General Genetics 150, 53-61.

Niaudet, B. \& EhrLich, S. D. (1979). In virro genetic labelling of Bacillus subtilis cryptic plasmid pHV 400 . Plasmid 2, 48-58.

Primrose, S. B. \& EHRLICH, S. D. (1981). Isolation of plasmid deiction mutants and study of their instability. Plasmid 6, 193-201.

Rutberg, B. \& HoCh, J. A. (1970). Citric acid cycle: gene-enzyme relationships in Bacillus subtilis. Journal of Bacieriology 104, 826-833.

SAmions, R. L. \& AnAgnostopoulos, C. (1982). Identification of a cloned DNA segment at a junction of chromosome regions involved in rearrangements in the trpE26 strains of Bacillus subtilis. FEMS Microbiology Letters 15, 265-268.

Sancar, A. A., HaCK, A. M. \& RupP, W. D. (1979). Simple method of identification of plasmid-coded proteins. Journal of Bacteriology 137, 692-693.

SPENCER, M. E. \& GUest, J. R. (1982). Molecular cloning of four tricarboxylic acid cycle genes of Escherichia coli. Journal of Bacteriology 151, 542-552.

Warburg, R. J. \& Molr, A. (1981). Properties of a mutant of Bacillus subtilis 168 in which spore germination is blocked at a late stage. Journal of General Microbiology 124, 243-253.

Weitzman, P. J. D. (1981). Unity and diversity in some bacterial citric acid-cycle enzymes. Advances in Microbial Physiology 22, 185-244. 